Egyptian Journal of Rabbit Science, 31(2): 107-132 (2021)

\title{
PHYSIOLOGICAL RESPONSE AND SEMEN QUALITY OF RABBIT BUCKS SUPPLEMENTED WITH SELENIUM AND TRIBULUS TERRESTRIS EXETRACT DURING SUMMER SEASON
}

\author{
M.E. El-Speiy, T.A. Sadak, M. A. Abd-Elaal and Hanaa. A. Moustafa \\ Anim. Prod. Res. Instit., Agric. Res. Cent., Egypt, Alexandria, Egypt \\ e.mail :Mohamed.elspeiy@yahoo.com
}

\begin{abstract}
The aim of this study
were found among all supplemented was to evaluate the effects of inclusion aqueous extract of Tribulus genuses (ETT) with selenium on semen quality and physiological response of mature buck rabbits during summer season. Thirty six of mature buck rabbits and forty-eight does of Californian breed were randomly divided into six equal treatment groups (6 buck +8 does per each). The first treatment group was fed on basal diet (unsupplied group) and served as control. The other five treatments were fed the same basal diet and orally supplied with $0.4 \mathrm{mg}$ $\mathrm{Se} / \mathrm{L} \mathrm{(Se),} 50 \mathrm{mg} \mathrm{ETT/kg} \mathrm{BW}$ (ETT1), $100 \mathrm{mg} / \mathrm{kg} \mathrm{BW}$ (ETT2), $0.4 \mathrm{mg} \mathrm{Se} / \mathrm{L}+$ $50 \mathrm{mg} \mathrm{ETT/kg} \mathrm{BW}(\mathrm{ETT1}+\mathrm{Se})$ and 0.4 $m g \quad \mathrm{Se} / \mathrm{L}+100 \mathrm{mg}$ ETT/kg BW $(E T T 2+S e)$, respectively.

The results indicated that the different supplied groups had a significantly higher follicle stimulating (FSH), luteinizing (LH), testosterone, progesterone and estrogen hormones levels than the control group. The groups supplemented with of ETT and Se showed high levels of FSH, LH, FT and $E_{2} 17 \beta$ than another groups. However, no significant differences groups regarding blood biochemical parameters. Administrations of ETT and Se significantly increased plasma total antioxidant capacity and immunoglobulin $M$ levels. On the other hand, the level of malondialdehyde was significantly decreased for the treated groups compared with the control group. Also, ejaculate volume, sperm motility, sperm concentration, cell integrity, fertility rate and litter size at birth were significant increases, while reaction time, abnormal sperm and dead sperm were significantly decreased. The groups ETT1+Se and ETT2+Se recorded height rate of fertility and increase number of litter size at birth. Treated groups showed statistically heaviest final body weight, body weight gain and lowest feed conversion compared with the control group.

Conclusively, extract Tribulus Terrestris (al-Hasakah) plant with selenium led to improve the activity of sex hormones, oxidative status and immunity, and the additives improved the quality of semen and increased
\end{abstract}


fertility and Litter size at birth abdominal size at birth during summer condition.
Key word: Tribulus Terrestris, semen quality, sex hormones, immune status.

\section{INTRODUCTION}

In rabbits, the quantity and quality of semen plays an important role in the fertility and reproduction of rabbits bucks (Oseni and Lukefahr, 2014). So, optimal reproductive results are achieved with artificial insemination or natural mating primarily because the procedures aim to maximize efficiency the probability of oocytes being fertilized; while quality of semen are highly changing between buck rabbits (Tusell et aL.,2012). Semen evaluation must provide information on the fertilizing ability of spermatozoa. The most pertinent parameters correlated with the fertility rate are the number of spermatozoa inseminated and their motility, in spite of the use of a single attribute is not sufficiently rigorous to prognosticate the fertilizing ability of the semen (Lavara et al., 2005).

Tribulus terrestris L. (TT) is a member of the Zygophyllaceae family, aqueous extract contains many compounds such as alkaloids, flavonoids oil, saponins, resins and nitrates (Abdul-Wahed, 2002). The biological properties of Tribulus extracts increased release of nitric oxide from endothelium and nerve termination it relaxes smooth muscles and increases angiogenesis converting enzyme inhibition (Sharifi et al.,2003). Another theory, it is believed that TT strongly affect the androgen metabolism, significantly increasing levels of testosterone or its precursors, and some studies indicate that this effect is due to the dominant component of the TT as protodioscin (Natasha et al.,2018). Tribulus terrestris have been extensively used as male sexual stimulants treatment of infertility, low sex drive and erectile dysfunction (Zhang and Chan, 2015). Abeer et al. (2012) reported that the beneficial effect of orally T.terrestris (150 mg / kg / day of an aqueous extract of TT) on testes can be attributed to antioxidant and metal chelating effect of $T$. terrestris.

Furthermore, the fruit of Tribulus terrestris has been used as aphrodisiac and to treated sexual dysfunction (Chhatre et al., 2014), possibility to promote hormone levels of testosterone and enhance premature ejaculation (Ghosian et al., 2013) and improved both sperm motility and count (Khoradmehr et al., 2010).

Selenium ( $\mathrm{Se}$ ) as a trace mineral is play pointedly involves in numerous biological functions like growth, immunity, antioxidant status (Murray et al., 
2000), production and reproductive performance, necessary component of selenoproteins (Kryukov et al., 2003 and Pappas and Zoidis, 2012).

Selenium plays major roles for spermatogenesis, and maintaining sufficient viability of spermatozoa and had ability to diminishing abnormalities of spermatozoa through direct effect on raise antioxidant status (Ebeid, 2009). Selenium is essential for spermatogenesis and its deficiency results in deterioration sperm motility and morphological abnormalities in rodents (Kehr et al., 2009).

Therefore, the objective of this study was to evaluate the effect aqueous extract of Tribulus terrestris (TT) and selenium (Se) on semen quality, antioxidant capacity, blood biochemical parameters and fertility of buck rabbits.

\section{MATERIALS AND METHODS}

\section{Housing and management:}

The present study was carried out at a City of Scientific Research and Technological Applications Alexandria, Egypt, from the medal of July to the medal of October. The work aimed to study the effect of Tribulus Terrestris (TT) and selenium dioxide supplementations on semen quality and fertility rate of Californian buck rabbits. The ambient temperature and relative humidity were recorded daily and daily photoperiod (daylight length) was obtained from a nearby Meteorological station as shown in Table (1).

The temperature-humidity index (THI) was calculated using the equation: $\mathrm{THI}=\mathrm{db}^{\circ} \mathrm{C}-\left[\left(0.31-0.31(\mathrm{RH})\left(\mathrm{db}^{\circ} \mathrm{C}-14.4\right)\right]\right.$, where $\mathrm{db}{ }^{\circ} \mathrm{C}$ is the dry bulb temperature and $\mathrm{RH}$ the relative humidity percentage/100. The obtained THI values were then classified as follows: $<27.8=$ absence of heat stress, 27.8 to $<$ $28.9=$ moderated heat stress, 28.9 to $<30.0=$ sever heat stress and 30 and over = very sever heat stress (Marai et al., 2001). Animals were kept in clean, separate wire-floor metal cages $(50 \mathrm{~cm}$ length $\times 45 \mathrm{~cm}$ width $\times 40 \mathrm{~cm}$ high), maintained under standard laboratory conditions and kept the managerial condition, healthy, hygienic and clinically free of external and internal parasites.

\section{Aqueous extraction of tribulus terrestris}

Tribulus terrestris (TT) was collected from the local commercial in Alexandria city. Then, the dried material was ground with a blender. The powder was kept in glass bottle inside a refrigerator $\left(20{ }^{\circ} \mathrm{C}\right)$ until starting the experiments. The plant powder was thoroughly mixed with boiled distilled water for 24 hours. Then, the mixture was filtered through a Whatman No.1 
Table: 1: Ambient temperature $\left({ }^{\circ} \mathrm{C}\right)$, relative humidity $(\%)$, temperature humidity index (THI) and photoperiod (h) during the experiment period

\begin{tabular}{|l|c|c|c|c|c|c|c|}
\hline Parameters & $\begin{array}{c}\text { Mid- } \\
\text { July }\end{array}$ & August & September & $\begin{array}{c}\text { Mid- } \\
\text { October }\end{array}$ & Overall & SEM & $\begin{array}{c}\text { P- } \\
\text { Value }\end{array}$ \\
\hline $\begin{array}{l}\text { Ambient } \\
\text { temperature }\left({ }^{\circ} \mathbf{C}\right.\end{array}$ & $31^{\mathrm{b}}$ & $32^{\mathrm{a}}$ & $31^{\mathrm{b}}$ & $28^{\mathrm{c}}$ & $\mathbf{3 0 . 5}$ & 0.4 & 0.001 \\
\hline $\begin{array}{l}\text { Relative } \\
\text { humidity (\%) }\end{array}$ & $76^{\mathrm{a}}$ & $73^{\mathrm{b}}$ & $76^{\mathrm{a}}$ & $76^{\mathrm{a}}$ & $\mathbf{7 5 . 3}$ & 0.08 & 0.001 \\
\hline THI & $29^{\mathrm{b}}$ & $31^{\mathrm{a}}$ & $30^{\mathrm{b}}$ & $27^{\mathrm{c}}$ & $\mathbf{2 9 . 3}$ & 1.2 & 0.001 \\
\hline Photoperiod(h) & 14 & 13 & 12 & 11 & $\mathbf{1 2 . 5}$ & 0.8 & 0.001 \\
\hline
\end{tabular}

a,b,c Means within a row with different superscript letters are significantly.

THI values were then classified as follows: $<27.8=$ Absence of heat stress, 27.8 to $<28.9$

$=$ Moderated heat stress, 28.9 to $<30.0=$ Sever heat stress and 30 and over $=$ Very sever heat stress (Marai et al ., 2001 and 2008).

filter paper and centrifuged for 15 minutes at $5000 \mathrm{rpm}$. The supernatant was collected and evaporated under reduced pressure at $37^{\circ} \mathrm{C}$ (Sara et al., 2017).

The major component in Tribulus terrestris extract (TTE) is methyl linolenate $(18.56 \%)$, Also, the higher percentage of fatty acid is the heptadecanoic acid (33.56\%). Meanwhile, carbohydrate and amino acid revealed the presence of inulin (5.61\%) and glutamic acid (2.85\%), respectively, Saponin yield is $7.38 \%$ and phenolic and flavonoid contents (11.16 and 6.076\%), respectively (Nagwa et al., 2018).

\section{Selenium:}

Selenium dioxide $\left(\mathrm{SeO}_{2}\right)$ used as source of $\mathrm{Se}$, which reacts with water particularly hot water, to give selenious acid, a weak acid that is corrosive stable to light molecular weight is $110.97 \mathrm{~g} / \mathrm{mol}$.

\section{Experimental design:}

The experiment was dune offer tow stage:

First stage: a total number of 36 un mature Californian rabbits buck (aged 4 month) with initial body weight of $2150 \pm 10.33 \mathrm{~g}$ were randomly divided into six treatments (each one consisting from 6 individual replicate with one buck) to study the effect of orally supplementation of ETT with selenium (selenium dioxide used as source of Se) in buck rabbit's semen quality. During this stage, rabbit buck was administered orally via drinking water daily with tow dose of $50-100 \mathrm{mg} / \mathrm{kg} \mathrm{BW} /$ day/rabbi and $0.4 \mathrm{mg}$ Se /litter drinking water for 8 weeks (from 4 -6 month, spermatogenesis period approximately). Also, the experimental dosages were continually used for bucks during the second stage. 
Experimental treatments as follows:

Group1: unsupplied group used as a control group (Control).

Group2: supplied with $0.4 \mathrm{mg}$ Se / litter/day drinking water (Se).

Group3: supplied with $50 \mathrm{mg}$ ETT /kg BW / day/rabbit (ETT1).

Group4: supplied with $100 \mathrm{mg}$ ETT /kg BW/ day/rabbit (ETT2).

Group5: supplied with $50 \mathrm{mg}$ ETT/kg BW/ day/rabbit + 0.4mg Se / litter/day (ETT1+Se).

Group6: supplied with100 mg ETT/kg BW/day/rabbit + 0.4mg Se/ litter/day (ETT2+Se).

Second stage: the previous bucks were used for fertilize dose to study the effect of experimental supplementation agent on fertility rate and dose litter size at birth of the different treatments. These animals represented progeny of pool semen and artificial 8 does in each group (Lopez and Alvariño, 2000). Fortyeight mature untreated does (aged 6 months) with initial body weight $3050 \pm 10.7 \mathrm{~g}$ of witch were randomly divided into six treatments with 8 individual replicate. Only receptive females (red color of vulvae lips) were inseminated with about 40 million spermatozoa in three sequence parities. Does were artificially inseminated with the control and the other tested supplementations. Does were injected with $0.8 \mathrm{mg}(0.2 \mathrm{ml})$ of gonadotropinreleasing hormone analogue (Buserelin, Suprefact ${ }^{\circledR}$, Hoechst-Roussel, Germany (Receptal)) immediately at the time of insemination according to (Boussin, 1989). Does were inseminated artificially with semen extenders, which described previously. The insemination procedure was as described by (Adams, 1981).

Feed and drinking water were offered on ad libitum basis. All rabbits were fed the same basal diet formulated according to the nutritional requirements of the National Research Council (NRC, 1977), which ingredients and calculated chemical composition are displayed in Table 2.

\section{Semen collection:}

Semen was collected twice weekly (during the second stage) from each buck by artificial vagina using a female teaser rabbit with an interval of 3-4 days between successive ejaculation .The temperature of the inner rubber sleeve of the artificial vagina was adjusted to $41-43^{\circ} \mathrm{C}$ and the lubrication of the inner sleeve was performed using white Vaseline. At four month of bucks age, started the training period with artificial vagina for 2 months by collected two ejaculate per buck per week. Will the does be 8 months old, semen collection was began 


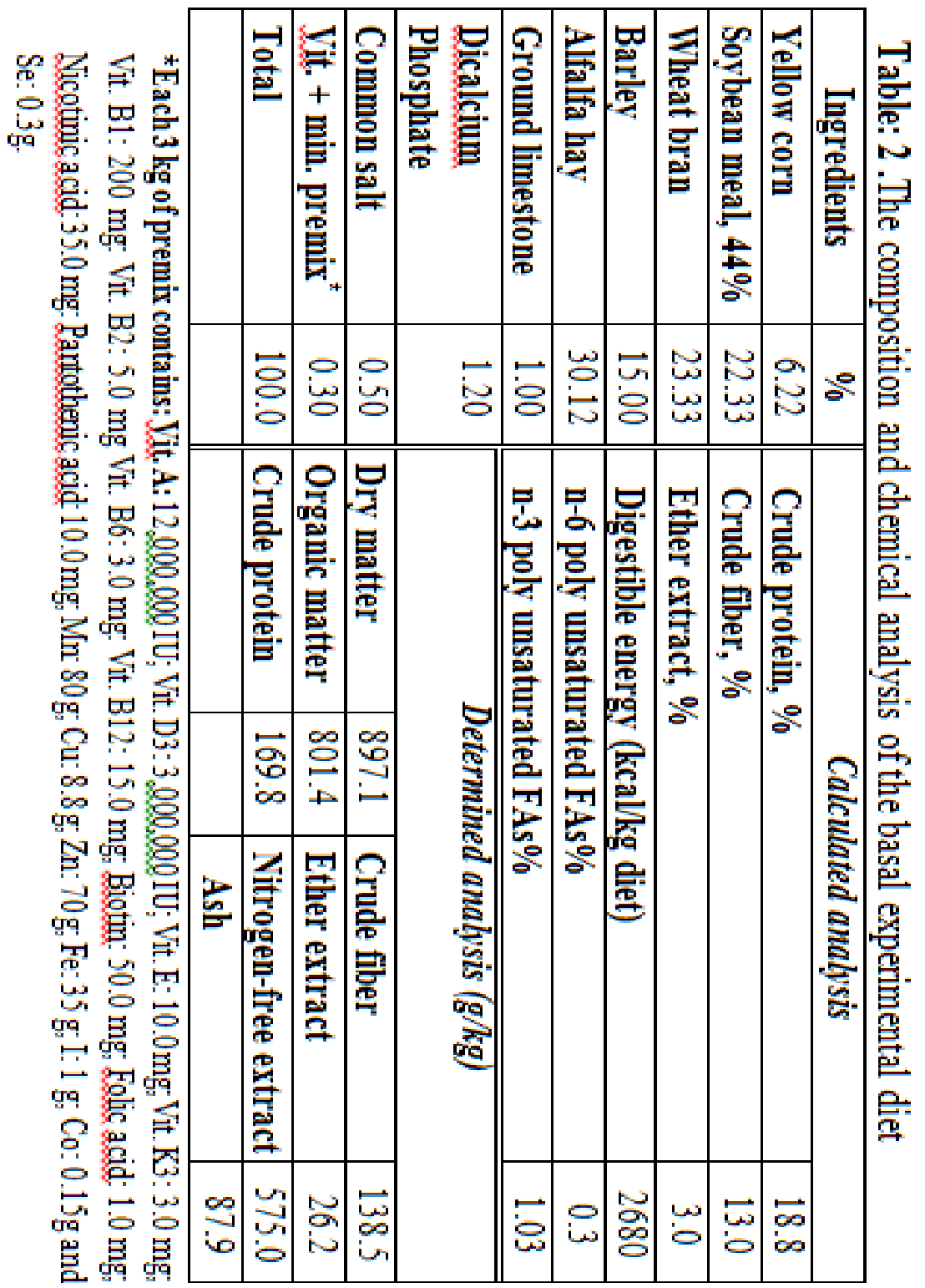


for semen examination. During collection period (8 weeks), two ejaculates per buck per week were collected. All ejaculates (average 560-576 samples for all treatment during semen collection period) were stored at $37{ }^{\circ} \mathrm{C}$ in a water bath until evaluation, not later than 10 minutes after collection.

\section{Semen characteristic:}

Physical semen characteristics i.e. reaction time (RT) determined by (Chibundu, 2005).

Ejaculate volume (Ej V, ml), determined by using graduated tube. Spermatozoa concentration (SC), number of sperms per ml) was counted using a haemocytometer according to Smith and Mayer (1955). For evaluation of percentage of sperm advanced motility (AdM, drop of semen was examined under the low power of microscope using a hot stage at $37{ }^{\circ} \mathrm{C}$.

Percentage of motile sperm (Sd) was estimated by a phase-contrast microscope according to Melrose and Laing (1970).

Spermatozoa concentration percentage of live and abnormal sperms (SAb) were determined after staining with eosin and nigrosine (Blom, 1950) and then calculated as a percentage out of randomly chosen 100 sperm counted, total sperms in the ejaculate $\left(10^{6}\right.$ /ejaculate), number of motile sperms per ejaculate were estimated in residual semen samples.

\section{Rabbit libido:}

Libido (sexual desire) was estimated by observation of the reaction time (in seconds) from the time of introducing the doe to the buck until the buck start to mount and ejaculate the first copulation.

\section{Blood biochemical constituents:}

Blood samples (from bucks) were withdrawn at morning (8.00:9.00 h) from marginal ear veins under vacuum in clean tubes without heparin for each treatment group before access feed and water. Serum was obtained by centrifugation the blood $3500 \mathrm{rpm}$ for 20 minutes and stored at $-20^{\circ} \mathrm{C}$ for later analysis. The blood biochemical parameters total plasma protein(TP), albumin(Alb) were measured by the methods Doumas et al. (1981), globulin(GLo) was calculated, cholesterol, aspartate aminotransferase (AST), alanine aminotransferase (ALT), triglycerides (TG) (Fasati and Prencipe, 1982), high-density lipoprotein (HDL), low-density lipoprotein (LDL) using the method of Stein (1986). Serum samples were subjected to biochemical analysis of alanine aminotransferase (ALT) and aspartate aminotransferase (AST) activities (Reitman and Frankel, 1957). All biochemical parameters were 
analyzed by commercially available kit methods. GNW-Model: SM-721 Spectrophotometers, Absorbance Microplate Reader and other laboratory equipment aids were used for biochemical analysis.

\section{Determination hormones, immune response and serum Antioxidant:}

Bucks serum concentrations of estrogen $\left(\mathrm{E}_{2} 17 \beta\right)$, progesterone $\left(\mathrm{P}_{4}\right)$, free testosterone (FT), follicle stimulating hormone (FSH) and luteinizing hormone (LH) levels were determined by using enzyme-linked immunosorbent assay (ELISA) kits according to Odell and Parlow (1981).

Different types of immunoglobulins in blood serum (IgG and $\operatorname{IgM}$ ) were determined using commercial ELISA kits (Kamiya Biomedical Company, USA). Biochemical analyses of serum total antioxidant capacity (TAC) and malonaldehyde (MAD) were determined using commercially available kits methods using spectrophotometers, (GNW-Model: SM-721) according to Ippoushi et al., (2005).

\section{Statistical analysis:}

Using SAS (2002), the data were statistically evaluated using Snedecor and Cochoran (1982) fully randomized design. The following model was used:

$$
\mathrm{Y}_{\mathrm{ij}}=\mu+\text { Tri }+\mathrm{e}_{\mathrm{ij}}
$$

Where, $Y_{\mathrm{ij}}=$ Observations, $\mu=$ Overall mean, Tri $=$ Effect of $i^{\text {th }}$ treatment $(\mathrm{i}: 1-$ $6), \mathrm{e}_{\mathrm{ij}}=$ Experimental error.

The significant means differences among groups were separated by Duncan's multiple rang test (Duncan, 1955).

\section{RESULTS AND DISCUSSION}

\section{Temperature degrees $\left({ }^{\circ} \mathrm{C}\right)$ and relative humidity (\%):}

In Table 1 are shown the change of temperature during the experimental period (summer season). The mean of ambient temperature, relative humidity and THI and photoperiod during the experimental interval were 30.5, 75.3, 29.3 and $12.5 \mathrm{~h}$, respectively.

The data demonstrated that the ambient temperature during July, Agust, September and October are $31,32,31$ and $28.0^{\circ} \mathrm{C}$ with overall average 30.5 . These results indicated that the rabbits exposed to sever HS during summer session. These observations are in agreement with that reported by Marai et al. (2001 and 2008). 


\section{Effect of ETT on physiological response: Hormonal profile:}

Table 3 illustrated that the group supplied with $50 \mathrm{mg}$ ETT (ETT1) had a significantly higher FSH, LH, FT and $\mathrm{E}_{2} 17 \beta$ concentrations compared with control group and the other experimental groups except for the concentration of $\mathrm{E}_{2} 17 \beta$ for the group supplied with $0.4 \mathrm{mg} \mathrm{SE} / 1$ of water. While the group supplemented with $100 \mathrm{mg}$ ETT + Se $($ ETT2+Se) showed the lowest levels of $\mathrm{FSH}, \mathrm{LH}$ and $\mathrm{E}_{2} 17 \beta$ than the control and the other experimental groups. Also, the groups supplied with $100 \mathrm{mg}$ ETT (ETT2) or $100 \mathrm{mg}$ ETT + Se (ETT2+Se) showed the lowest levels of $\mathrm{E}_{2} 17 \beta$ than the control and the other experimental groups. These results are in agreement with Mohammad et al. (2013) who recorded that treatment with TT can increase the hormones level of FT, P4, $\mathrm{E}_{2} 17 \beta$ and LH. Antonio et al. (2000) recorded that the upswing in LH impact to a signal for testosterone to increase. Also, Kazim et al. (2016) recorded that highest effectiveness of Tribulus on Serum testosterone levels. The same result recorded by Georgiev et al. (1988) it was shown that TT extract administration improved LH also sperm production and testosterone levels in ram. Also, Karimi et al. (2012) who mentioned that dioscin is a important component of Tribulus terrestris that increases male sexual ability by increasing free testosterone concentration and modulating estrogen, progesterone and pregnenolone levels.

Regarding the role of Se, Table (3) showed that serum FT concentration for the group supplied with only Se was increased compare with that recorded on the control group. That result are in agreement with similar response detected by El-Sisy et al. (2008) and Ibrahim and Mohamed, (2018) who indicated that supplemented male Baladi goats fed a diet with selenium yeast led to improved their reproductive efficiency and increase serum testosterone compared to control group. Also, Abdel-Waretha et al. (2019) recorded the same result in rabbit bucks supplemented nano-selenium.

Interestingly, Gauthaman and Adaikan (2005) examined the hormonal effects by TT extracts in rabbits and they detected an increase in androgenic hormone levels and erectile dysfunction improvement.

They all illustrated that TT had aphrodisiac activity, due to its androgen rising property. Also, Nasroallah et al. (2013) showed that TT raising testosterone by increasing gonadotropin releasing hormone which in modify stimulates the production of LH and follicle stimulating hormone, testosterone and that reflected on raising fertility and libido. 


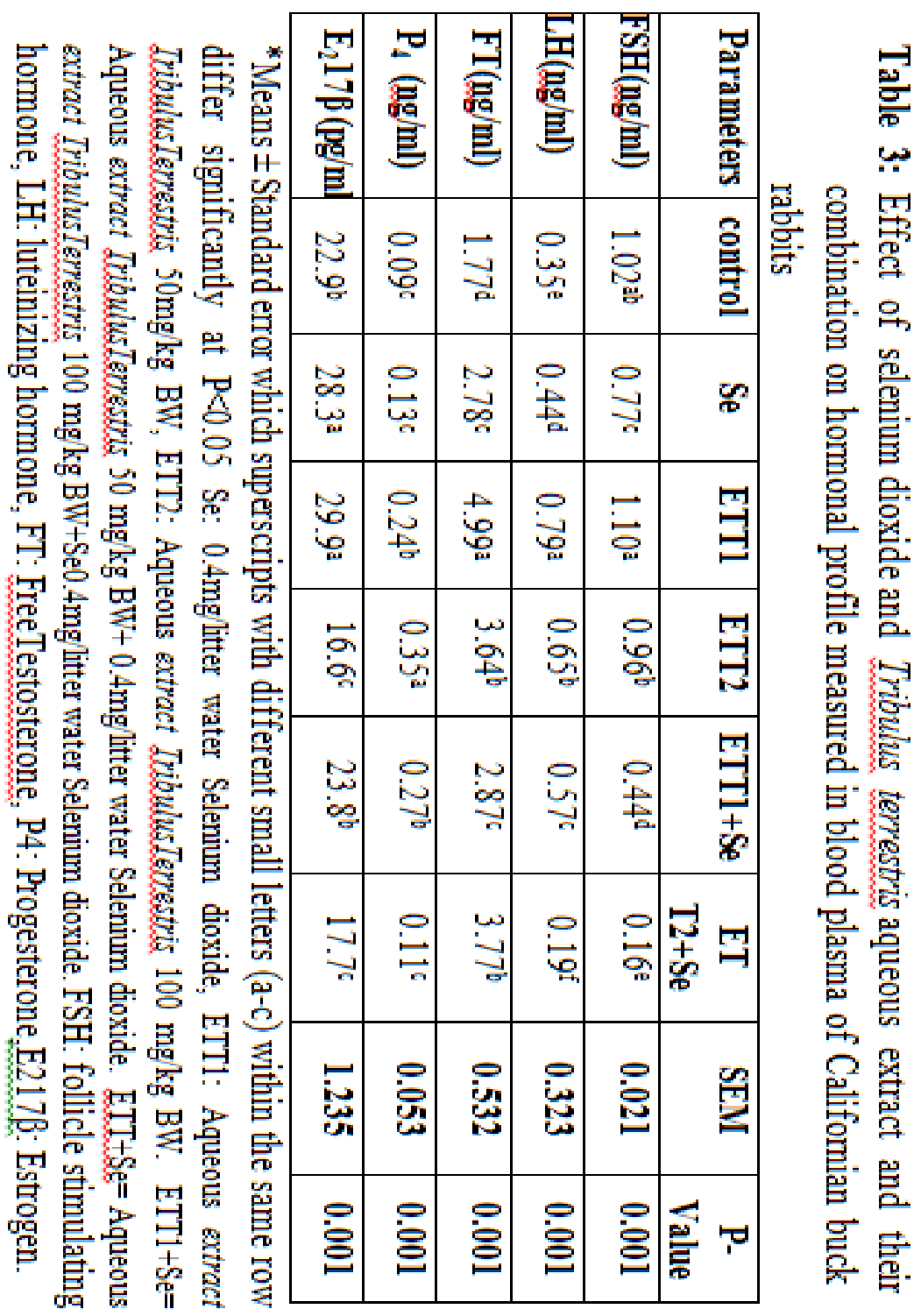




\section{Blood biochemical parameters:}

Serum-biochemical blood data were summarized in Table 4. There were no significant differences in activity of AST, ALT, ALP or concentration of TP, $\mathrm{ALb}$ and GLO between the control and experimental groups during tested period. Furthermore, no significant changes were observed in the concentrations of creatinine compared to the control group. Also, lipid profile (TG, HDL and LDL) were not significant differences for all experimental groups compared with control group.

However, No significant changes were observed in the biological parameters alterations in components synthesized by liver like enzymes and proteins. Even the combination between ETT and Se doesn't affected or significantly changed parameters. In addition, ETT plant, which medicine had no toxic effects on kidney functions so it's likely to have a protective effect on kidney. These results are in agreement with a previous study by Abdel-Kader et al. (2016) who confirmed the positive effect of the plant on the kidney tissues and function. These results may be due to presence of abundant bioactive phytochemicals as glycosides, saponins, flavonoids, phytosteroids, alkaloids, glycosides, and numerous constituents in TT (Shama et al., 2019). Disagreement with our results, Grigorova et al. (2008) and Mohsen and Mehran (2016) showed that hens serum total cholesterol tended to be lower in TT treated group relative to control birds. On the other hand, Haytham (2016) recorded that a significant decrease in total serum cholesterol, blood glucose. Also, the previous researchers indicated that the level of serum alkaline phosphatase is no difference among the hens of the all groups. However, the carnet results indicated that Se had no effect on biochemical blood parameters, while, Emara et al. (2019) reported that feed rabbit different source of Se (Nano-selenium and sodium selenite) led to significantly decrease TC, LDL, HLD,VLDL, triglycerides, and phospholipids. Also, El-Kholy et al. (2019) revealed that rabbits supplemented with different source of Se caused significant increases in total protein (TP), albumin (Alb) and globulin (Glb) but these increases were still within normal range.

\section{Serum antioxidant and immunoglobulin status:}

Results Table 5 indicated that there were no significant differences on TAC, MAD and IgG activity among the control and experimental groups during tested period. Furthermore, significant decreasing in IgM for treated groups supplied with ETT1+Se and ETT2+Se compare to control. Our date indicated that the combinations between ETT and Se had appositive results than supplementation of each of them individuals. These results are in agreement 


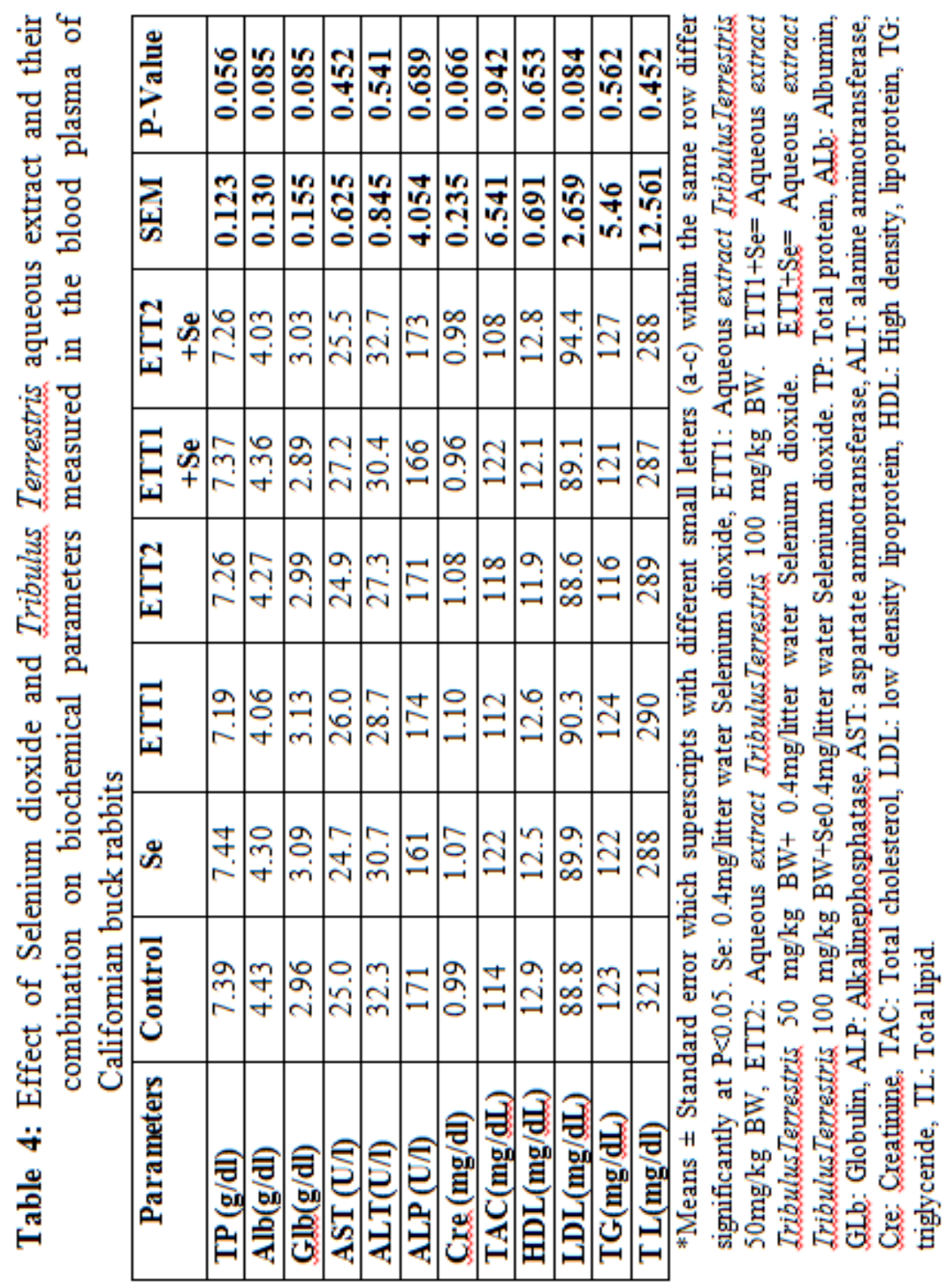


FEEDING OF SELENIUM \& TRIBULUS TERRESTRIS EXETRACT OF BUCKS 119

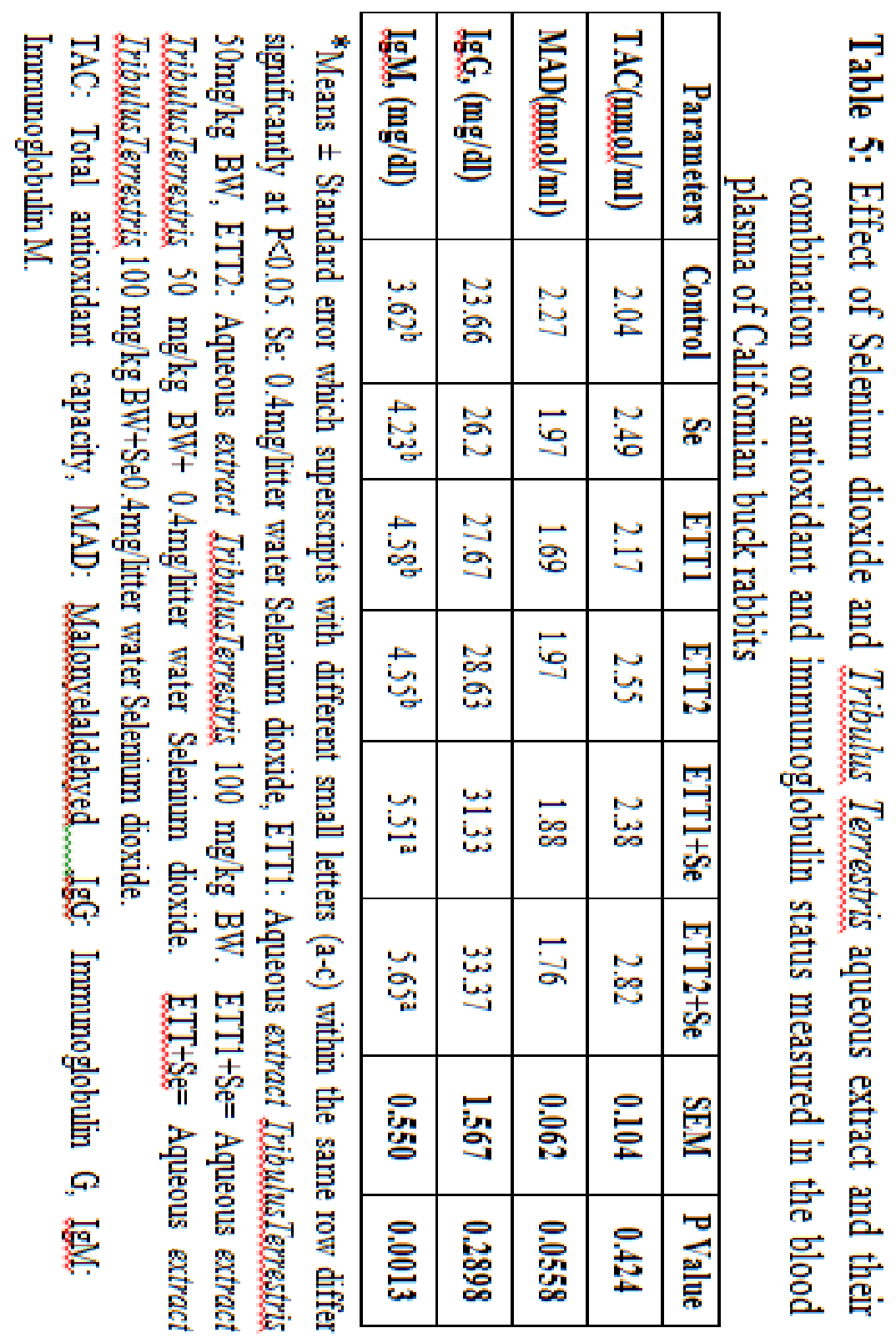


with Emara et al. (2019) who recorded that the supplemented diet with nanoselenium and sodium selenite cause significantly improving on the status of the estimated antioxidants. Another study by Dokoupilová et al. (2007) which recorded that supplemented Se in organic or inorganic forms to provide a margin of safety of immunity against deficiency and to maintain productive performance. Same result obtained by El-Kholy et al. (2019) who mentioned that supplemented rabbit diet with organic or inorganic Se form increased in immunoglobulin concentrations with Se addition could be an indication of Se either in organic or inorganic form induces earlier maturation of the humeral indication of Se either in organic or inorganic form induces earlier maturation of the humoral immune responses. Also, higher serum $\mathrm{IgG}$ levels in rabbits supplemented with Se indicate that Se is effective in improving humeral immunity. Since, Meissonnier et al. (2008) demonstrated that limitation of the levels of serum immunoglobulin such as $\operatorname{IgA}, \operatorname{IgG}$ and $\operatorname{IgM}$ are the most common methods of testing humeral immune responses. On the other hand, Dutt-Roy et al. (2017) observed that an in vivo study that the treatment rat with TT extracts raised the activities of TAC as catalase, superoxide dismutase and decline the malondialdehyde (MDA) level.

\section{Productive performance:}

In Table 6 are shown the values of final body weight, body weight gain, feed intake and feed conversion at the end of the experiment. The growth rabbit performances from all treated groups supplied with both levels of ETT with our without Se had a significantly heaviest final body weight, body weight gain and the best feed conversion comparison with the control and Se groups. However FI was not significantly change among experimental groups. The results obtained are in accordance with other study, who confirmed a significant increase of body weight in rats supplemented with different doses of TT (Gauthaman et al., 2003). This effect can be explained by the androgenic role of the effective product, which perhaps stimulates the appetite. Androgens play an important role in the growth and development of reproductive tissue and in the differentiation of other tissues (Desislava et al., 2019).On the other hand, Dimitrov et al. (1987) and Çek et al. (2007) both researcher illustrated an increase in body weight at the same trend Valchev et al. (2009) documented that the rabbit supplemented with TT extract increase in the average daily gain and improved feed efficiency as compared to the control. Finely, El-Badry et al. (2019) are concordant with our study results that live body weight and body weight gain and lowest feed conversion were significantly with rabbits received 


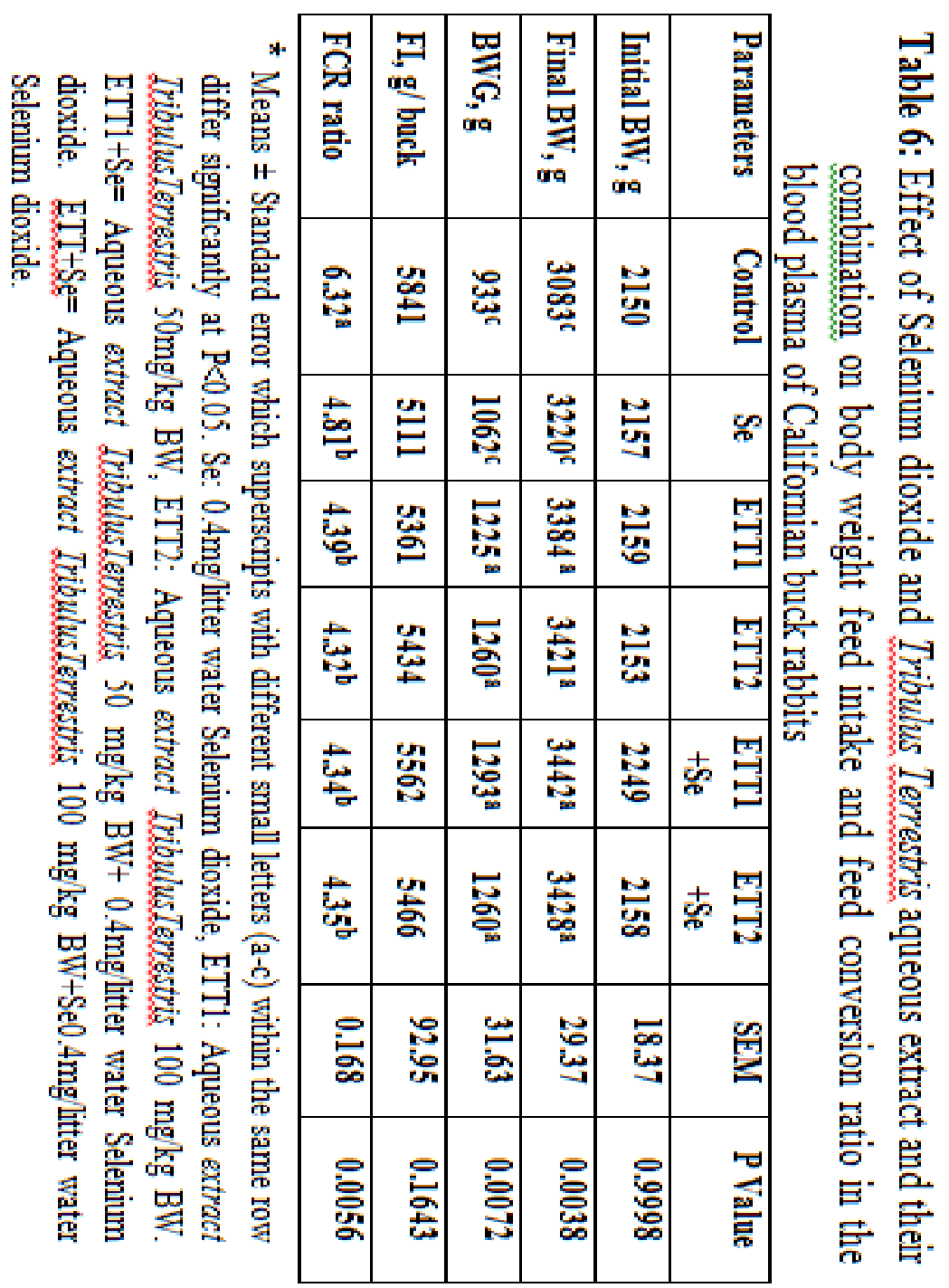


nano-Se. Regarding the role of selenium on productive performance, our results are in agreement with Ebeid et al. (2012) who illustrated that consumed rabbits a diet supplemented with organic Se had heaviest live body weight and daily weight gain compared with control group. However, are in contrast the present results Dokoupilová et al. (2007) who showed that body weight gain of growing rabbits did not significantly affect by adding dietary selenium.

\section{Semen quality:}

Values for measured sperm parameters are illustrated in Table 7. There were significantly improving on rabbit semen quality (EjV, AdM, SC, CI, FR and LSB) for the all supplemented groups with different agents compared with the values recorded for control group. However, groups supplemented with ETT + Se recorded the significantly or numerically values and completely archives the adverse effect of HS of the previous parameter. Excellent semen quality is desired for achieving adequate fertility in mammals (Dalton, 2011) inappropriate environmental cues lead to decreases in semen quality and fertility of farm animals (Rasooli et al., 2010).

Exposing to heat stimulates the hypothalamo-pituitary-adrenal axis activity evoking the sympathetic system functions, which increase levels of free radicals, cortisol level and imbalances in the antioxidant-defense status (Ahmad et al., 2012) causes decline the fertility by effects on ejaculate volume, sperm motility, number of motile sperm per ejaculate, sperm-cell concentration and total sperm-output of the buck rabbits (Alsaied et al., 2008). The present study are in agreement with those of Kazim et al. (2016) who documented that supplemented rat with TT extracts showed highest total sperm motility percentage, increase in sperm counts. Oliveira et al. (2015) explained the mechanism of TT extract, it has been concluded that the ethanol extract of $T$. terrestris influences spermatogenesis, as shown by the clear changes in the tubular compartment of the testes, such as increases in the total tube length, tubular volume and height of the seminiferous tubules epithelium. The hexane and aqueous soluble fraction in the methanol fractions promoted changes in the intratubular compartment because they increased the nuclear volume, cytoplasmic volume and individual volume of Leydig cells in male Wistar rats. Bitzer et al. (2013) recommended that in vitro addition of TT extract to human sperm could affect male fertility capacity. The incubation of human semen with TT extract significantly enhanced the total sperm motility, number of progressive motile spermatozoa, and curvilinear velocity.

Regarding the role of Se on semen quality, our results agree with result obtained by Ewuola and Akinyemi (2017) who reported that buck rabbits 


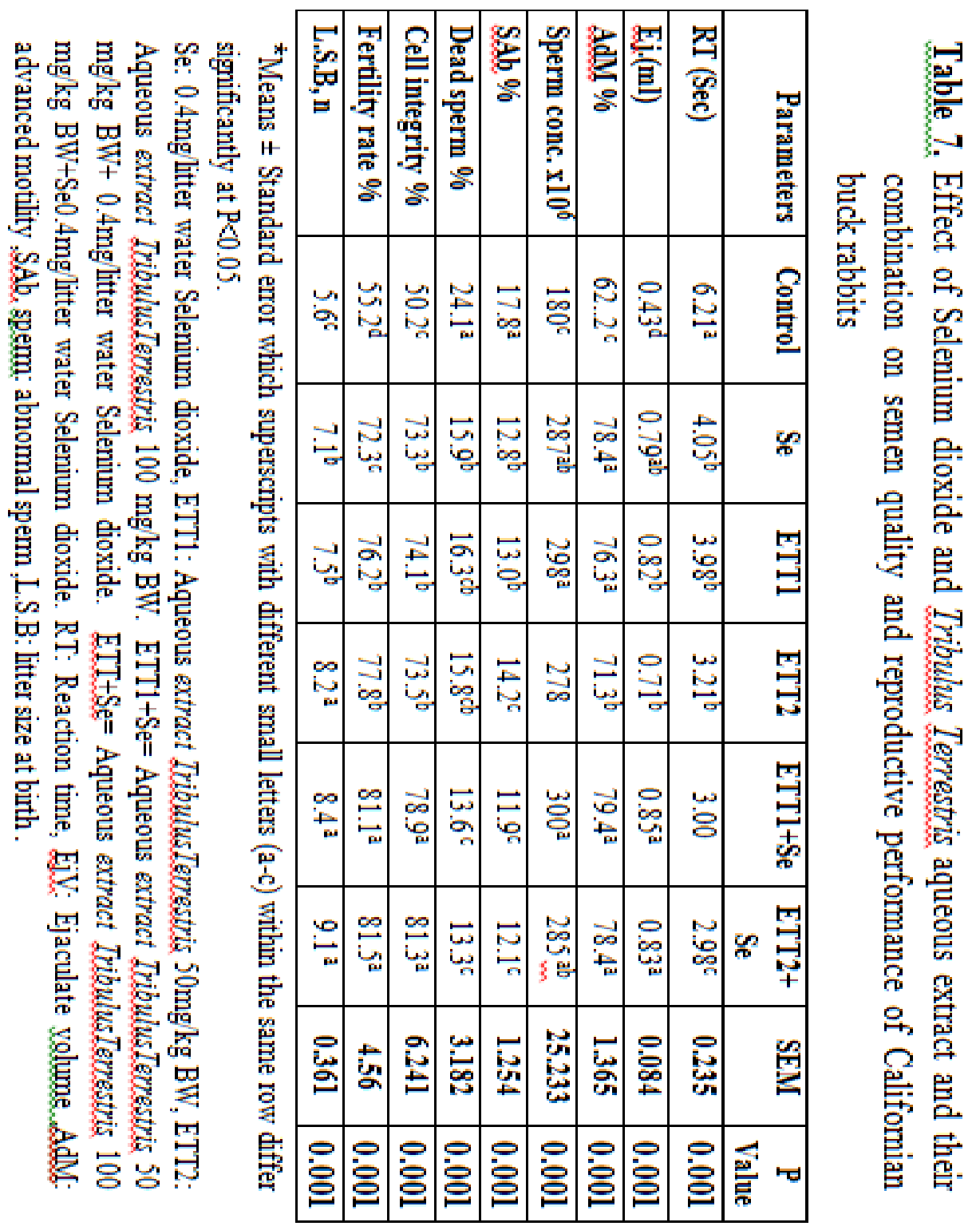


supplemented with organic selenium increased significant volume, mass activity, progressive motility, and live sperm cells and sperm concentration, also, decline percentage dead and abnormality sperm. Another study by Nourhan et al. (2020) recorded that supplemented diet bucks rabbits with organic selenium had lower reaction time, higher ejaculate volumes, sperm concentration and percentages of sperm progressive motility, live sperm, sperm with integrated membranes, and total functional sperm compared to the values obtained with the control diet. Also, they indicated that, the kindling rates, litter size, and weight at birth of females mated with males fed the organic selenium diet were significantly higher than those of females mated with males fed the control diet.

Conclusively, from these results it could be concluded that extract Tribulus terrestris (al-Hasakah) plant with selenium led to improve the activity of sex hormones, oxidative status and immunity, and the additives improved the quality of semen and increased fertility and Litter size at birth abdominal size at birth during summer condition.

\section{REFERENCES}

Abdel-Kader, M.S.A.; Al-Qutaym, A.S.; Bin Saeedan, A.M.; Hamad, A.M. and Alkharfy, K.M. (2016). Nephroprotective and hepatoprotective effects of Tribulus terrestris L. growing in Saudi Arabia. J. Pharm. Pharmacogn Res, 4(4), 144-152.

Abdel-Waretha, A.A.A.; Ahmedb, c.A.E.; Hassana, H.A.; Abd El-Sadekd, M.S.; Ghazalahf, A.A. and Lohakareg, J. (2019). Nutritional impact of nano-selenium, garlic oil, and their combination on growth and reproductive performance of male Californian rabbits. Animal Feed Science and Technology , 249, 37-45

Abdul- Wahed, M.K. (2002). Investigation of the steroidal saponins of Tribulus spp. widely grown in Iraq. M.Sc. Thesis, College of Pharmacy. Baghdad University.

Abeer, U.M.; Rasha, H.K. and Yasser, A.H. (2012). Effect of Aqueous Extract of Tribulus terrestris orally administration on some Biochemical Parameters in Castrated Male Rabbits. The Iraqi J. Vet. Med, 36 (2), 217221.

Adams, C.E. (1981). Artificial insemination in the rabbit. The technique and application to practice. J. Appl. Rabb, Res, 4, 10-13. 
Ahmad, A.; Rasheed, N.; Gupta, P.; Singh, S.; Siripurapu, KB.; Ashraf, GM.; Kumar, R.; Chand, K.; Maurya, R.; Banu, N.; Al-Sheeha, M . and Palit, G. (2012). Novel Ocimumoside A and B as anti-stress agents: modulation of brain monoamines and antioxidant systems in chronic unpredictable stress model in rats. Phytomedicine ,19, 639-647.

Alsaied, A.M.; Habeeb, Fatma E.I.T.; Magdy, Z.N. and Kamel M.E. (2008). Evaluation of Physical Semen Characteristics of Male Rabbits Exposed to Different Climatic Conditions and Lighting Regimes Using Nuclear Techniques. The Egyptian Society of Nuclear Sciences and Applications (ESNSA) (Egypt); 1239 p; 9 p; 9. International Conference for Nuclear Sciences and Applications; Sharm Al Sheikh (Egypt): 11-14 Feb.

Antonio, J.; Uelmen, J.; Rodriguez, R. and Earnest, C. (2000). The effects of Tribulus terrestris on body composition and exercise performance in resistance-trained males. Int J Sport Nutr Exerc Metab, 10(2),208-215.

Bitzer, J.; Giraldi, A. and Pfaus, J. (2013). Sexual desire and hypoactive sexual desire disorder in women. Introduction and overview. Standard operating procedure. J. Sexual Med, 10(1),36-49

Blom, E. (1950). A One-Minute Live-Dead Sperm Stain by Means of Eosin Nigrosin. Fertility Sterility, 1, 176-177.

Boussin, D. (1989). Reproduction Et Insemination Artificielle En Cuniculture. Association Francaise de Cuniculture, Lempdes, Paris.

Çek, Ş.; Turan, F. and Atik E. (2007). Masculinization of convict cichlid (Cichlasoma nigrofasciatum) by immersion in Tribulus terrestris extract. Aquaculture International ,15(2), 109-119

Chhatre, S.; Nesari, T.; Somani, G.; Kanchan, D. and Sathaye, S. (2014). Phytopharmacological overview of Tribulus terrestris. Pharmacognosy Reviews, 8, 45-51.

Chibundu, U.C. (2005). Response of pre-pubertal bucks to administration of estradiol $\beta$. Project Report, Federal University of Technology, Owerri pp,30.

Dalton, JC. (2011). Semen quality factors associated with fertility. In Proceedings of Applied Reproductive Strategies in Beef Cattle, Institute of Agriculture and Natural Resources, 30 September-1 October, Boise, ID, USA.

Desislava, A.; Svetlana, G.;Natasha, G.and Elena, K. (2019). Dosedependent effect of tribulus terrestris dry extract on reproductive organs of growing male rabbits. Maced. J. Anim. Sci, 9 (1), 19-23. 
Dimitrov, M.; Georgiev, P. and Vitanov, S. (1987). Use of Tribestan on rams with sexual disorders. Veterinarno Meditsinski Nauki, 24(5), 102-110.

Dokoupilová, A.; Marounek, M.; Skřivanová, V. and Březina, P. (2007). Selenium content in tissues and meat quality in rabbits fed selenium yeast. Czech Journal of Animal Science ,52, 165-169.

Doumas, B. (1971). Colorimetric method for albumin determination. Clin. Chim. Acta, 31,87-92.

Duncan, D.B. (1955). Multiple ranges and multiple F. test. Biometrics ,11-42.

Dutt-Roy, R.; Kayalvizhi, E.; Chandrasekhar, M. (2017). Evaluation of the antidepressant activity of Tribulus terrestris in diabetic depression in rat model. Int. J. Pharm. Sci. Res, 8,5392-5399. [Google Scholar]

Ebeid, T.;. Zeweil, H; Basyony, M. and Badry H. (2012). The impact of incorporation of organic selenium into meat on growth performance, antioxidative status, and immue response in growing rabbits. In: Proc. Of the 10th World Rabbit Congress, September 3-6, Sharm El-Sheikh, Egypt, pp,861-864.

Ebeid. T. A. (2009). Organic selenium enhances the antioxidative status and quality of cock semen under high ambient temperature. British Poultry Science, 50 (5), 641-647.

El-Badry, A.S.O.; Mahrousa, M.H.; Mosalm, G.A.G.; Ekram, S.A. and ElAasar, T.A. (2019). Influence of ingestion of nano- selenium on growth performance, antioxidative and mutagenicity status in somatic cells of new zealand white rabbits Egyptian Journal of Rabbit Science, 29 (1), 121.

El-Kholy, K.H. ;Tag El-Deen, H.T. ; Abd-El-Lateif ,A.I. and Aml I. M. (2019). Effects of dietary selenium sources on metabolic, enzymatic and immunoglobulin serum profiles in growing rabbits. Pak. J. Nutr,18 (5), 430-436.

El-Sisy, G. A.; M. A. Abdel-Razek; A. A. Younis; A. M. Ghallab and M. S. S. Abdou (2008). Effect of dietary zinc or selenium supplementation on some reproductive hormone levels in male Baladi goats. Global Vet, 2(2), 46-50.

Emara, S.S. ;El-Zaher, H.M.; Michael . M.I. and Eid, S.Y. (2019). Comparative Effects of Nano-Selenium and Sodium Selenite Supplementation on Blood Biochemical Changes in Relation to Growth Performance of Growing New Zealand White Rabbits. Arab J. Nucl. Sci. Appl, 52(4), 1-14. 
Ewuola, E. O. and Akinyemi, D. E. (2017). Semen Characteristics of Rabbit Bucks Orally Administered Exogenous L-Selenomethionine. Annual Research \& Review in Biology, Page, 1-8

Fasati, P. and Prencipe, L. (1982). Determination of plasma triglycerides. Clinical. Chem, 28: 2077.

Gauthaman, K.; Adaikan, PG. (2005). Effect of Tribulus terrestris on nicotinamide adenine dinucleotide phosphate-diaphorase activity and androgen receptors in rat brain. J. Ethnopharmacol ,96(1-2),127-132.

Gauthaman, K.; Ganesan, A. P. and Prasad, R. N., (2003). Sexual effects of puncture vine (Tribulus terrestris) extract (protodioscin): An evaluation using a rat model. Journal of Alternative and Complementary Medicine, 9, 257- 265 .

Georgiev, P.; Dimitrov, M. and Vitanov, S. (1988). Effect of Tribestan (from Tribulus terrestris) on plasma testosterone and spermato-genesis in male lambs and rams. Veterinarna Sbirka, 86(3), 20-2.

Ghosian, M.M.H.; Khalili, M.; Maleki, M. and Ahmad, M.E. (2013). The Effect of oral feeding of Tribulus terrestris L. on sex hormone and gonadotropin levels in addicted male rats. Int J Fertil Steril, 7, 57-62.

Grigorova, S.; Vasileva, B.; Kashamov, V.; Sredkova, S. and Surdjiiska. (2008). Investigation of Tribulus terrestris extract on D.the biochemical parameters of eggs and blood serum in laying hens. Archiva Zootechnica, 11(1), 39-44.

Haytham, M. D. (2016). Evaluation of Hematological and Biochemical Activity of Ethanolic Extract of Zygophyllum simplex Linn. in Wistar Rats. Pak. J. Biol. Sci,19 (4), 179-184.

Ibrahim, E. M. and Mohamed, M.Y. (2018). Effect of different dietary selenium sources supplementation on nutrient digestibility, productive performance and some serum biochemical indices in sheep. Egyptian J. Nutrition and Feeds, 21 (1), 53-64.

Ippoushi, K.; Ito, H.; Horie, H. and Azuma, K. (2005). Mechanism of inhibition of peroxynitrite-induced oxidation and nitration by [6]-gingerol. Planta-Medica, 71, 563-566.

Karimi, J. H.; Malekzadeh, S.S. and Hoshmand, F. (2012). The effect of the Tribulus terrestris extract on spermatogenesis in the rat. Journal of Jahrom University of Medical Sciences, 9(4),8-13. 
Kazim, S.; Cemal, O.; Fatih, A.; Mehmet, T. ; Hasan, G.; Nurhan, S.; Gaffari T.; Ismet, Y.; Ibrahim, H. O. and Vijaya, J. (2016). Comparative evaluation of the sexual functions and $\mathrm{NF}-\kappa \mathrm{B}$ and $\mathrm{Nrf} 2$ pathways of some aphrodisiac herbal extracts in male rats. $B M C$ Complementary and Alternative Medicine ,16,318.

Kehr, S. ;Malinouski, M.; Finney, L.; Vogt, S.; Labunskyy, V.M.; Kasaikina, M.V.; Carison, B.A.; Zhou, Y.; Hatfield, D.L. and Gladyshev, V.N. (2009). X-Ray Fluorescence Microscopy Reveals the Role of Selenium in Spermatogenesis. Journal of Molecular Biology, 389, 808-818.

Khoradmehr, A.; Khalili, MA.; Ramezani, M.; Adib, M.; Vahidi, S. and Moin, MR., (2010). Effects of Herbal Drug NOFODA on Sperm Parameters of Infertile Men. Int J Fertil Steril, 4, 12.

Kryukov, GV.; Castellano, S.; Novoselov, SV.; Lobanov, AV.; Zehtab, O.; Guigo, R.and Gladyshev, VN. (2003). Characterization of mammalian selenoproteomes. Science, 300,1439-1443.

Lavara, R. Mocé, E.; Lavara, F.; Viudes de Castro, M.P. and Vicente, J.S. (2005). Do parameters of semen quality correlate with the results of onfarm inseminations in rabbits? Theriogenology, 64, 1130-1141.

Lopez, J. and, Alvariño, J.M.R. (2000). Effects of added caffeine on results following a rtificial insemination with fresh and refrigerated rabbit semen. Anim. Rep. Sci., 58, (1-2), 147-154.

Marai, I.F.M.; Habeb, A.A.M. and Gad, A.E. (2001). Rabbits productive, reproductive and physiol ogical performance traits as affected by heat stress: a review. Livestock Production Science ,78, 71-90.

Marai, I.F.M.; Habeb, A.A.M. and Gad, A.E. (2008). Performance of New Zealand white and Californian male weaned rabbits in the subtropical environment of Egypt. Animal Science Journal, 79, 472-480.

Meissonnier, G.M.; Pinton, P.; Laffitte, J. A.; Cossalter .M and Gong Y.Y. (2008). Immunotoxicity of aflatoxin B1: Impairment of the cell-mediated response to vaccine antigen and modulation of cytokine expression. Toxicol. Applied Pharmacol, 231:142-149.

Melrose, D.R. and Laing, J.A. (1970). Fertility and infertility in domestic animals. Small Ruminant Res, 17:128 -159. 
Mohammad, H. G.; Mohsen, K.; Maryam; Mohammad, E. and Ahmad A. (2013). The Effect of Oral Feeding of Tribulus terrestris L. on Sex Hormone and Gonadotropin Levels in Addicted Male Rats .Int. J . Of Fertili And Sterility, 7( 1): 57-62.

Mohsen, A. and Mehran, T. (2016). Effects of adding aqueous extract of Tribulus terrestris to diet on productive performance, egg quality characteristics, and blood biochemical parameters of laying hens reared under low ambient temperature $\left(6.8 \pm 3{ }^{\circ} \mathrm{C}\right)$.Int. J . Biometeorol, 60(6): 867-71.

Murray, RK.; Granner, DK.; Mayes, PA.; Rodwell, VW. and Harper's. (2000). Biochemistry, 25th Edition, Mc Graw-Hill. Health Profession Division, USA;

N.R.C. (1977). National Research Council . Nutrient Requirements Of Domestic Animals. Nutrients requirement of rabbits. USA. National Academy of Science, Washington, D.C.

Nagwa, M. A.; Seham, S. El-Hawary; Doha, A. M.; Manal, S. A.; Dina, M. G. and Gamal, A. (2018). Phytochemical and Biological Studies of Tribulus terrestris L. Growing in Egypt. Int. J. Pharmacol, 14 (2),248-259.

Nasroallah, M.; Saman, H. and Zahra, M. (2013). Physiological and pharmaceutical effects of tribulus terrestris as a multipurpose and valuable medicinal plant. Int J Adv Biol Biom Res, 1(10):1289-1295.

Natasha, F.P.; Aryele, P.Iz.; Melina, B.S.; Cristiano,C.S. ;Andreas,S.L.; Mendez,F.G.; Daniela, S. and Francielli, W.S.C. (2018). Tribulus terrestris Protects against Male Reproductive Damage Induced by Cyclophosphamide in Mice. Oxidative Medicine and Cellular Longevity Volume 2018, Article ID 5758191,1- 9 .

Nourhan, S. Hosny; Nesrein, M.H.; Amr, S.; Morsy and Zahraa, R. Aboelezz (2020). Effects of Organic Selenium on the Physiological Response, Blood Metabolites, Redox Status, Semen Quality, and Fertility of Rabbit Bucks Kept Under Natural Heat Stress Conditions. Front.Vet.Sci,12 | https://doi.org/10.3389/fvets.2020.00290

Odell, WD. and Parlow, AF. (1981). Estimation of FSH test assay. Journal Of Clinical Investigation, 47, 25- 51.

Oliveira, NNPM.; Félix, MAR.,; Pereira, TCS.; Rocha, LGP.; Miranda, JR. and Zangeronimo, MG. (2015). Sperm quality and testicular histomorphometry of wistar rats supplemented with extract and fractions of fruit of Tribulus terrestris L. Brazarch Biol Techn ,58(6):891-897. 
Oseni, SO.and Lukefahr, SD. (2014). Rabbit production in low-input systems in Africa: situation, knowledge and perspectives - A review. World Rabbit Sci, 22: 147-160.

Pappas, A.C. and Zoidis, E. (2012). The Role of Selenium in Chicken Physiology: New Insights. In: Chickens: Physiology, Diseases and Farming Practices,Kapur, I. and A. Mehra (Eds.). Nova Science Publishers, New York, USA., and ISBN13: 9781620810279, 167.

Rasooli, A.; Jalali, MT.; Nouri, M.; Mohammadian, B. and Barati, F. (2010). Effects of chronic heat stress on testicular structures, serum testosterone and cortisol concentrations in developing lambs. Animal Reproduction Science , 117: 55-59.

Reitman, S. and Frankel, S. (1957). A colorimetric determination of serum AST and ALT enzymes. Amer. J. Clin. Path, 28 :56-58.

Sara, K.; Mitra, B.; Atefeh, A. and Farzane, E. (2017). Tribulus terrestris Extract Improves Human Sperm Parameters in vitro. Journal of. Evidence-Based Complementary and Alternative Medicine, 22(3):407412.

SAS, (2002). SAS /STAT Guide For Personal Computer, Proprietary Software. Version 9. SAS Institute Inc. Cary, North Carolina, USA.

Shama, I.Y.; Adam; Nesreen, A.; Ahdaf, M.A.; Ahmed, S.Y.A.; Maiada, M.; Abdallah, 1.A.A.; Anfal, M. and Sara, H. (2019). Evaluation of Toxicity and Anti-microbial Activity of Tribulus terrestris Fruits in Sudan. Asian J. Biol. Sci, 12 (2), 130-139.

Sharifi, A.M.; Darabi, R. and Akbarloo, N. (2003). Study of antihypertensive mechanism of Tribulus terrestris in $2 \mathrm{~K} 1 \mathrm{C}$ hypertensive rats: role of tissue ACE activity. Life Sci, 73(23): 2963-71.

Smith, J.T. and Mayer, D.T. (1955). Evaluation of sperm concentration by the hemacytometer method. Comparison of four counting fluids. Fertility and Sterility, 6: 271-275.

Snedecor, G.W. and W.G. Cochran (1982). Statistical Methods. 8th ed. Iowa State Univ., Press Ames, Iowa, USA

Stein, E.A. (1986). Textbook Of Clinical Chemistry, NW Tietz, ed. W.B. Saunders, Philadelphia, 879-886.

Tusell, L.; Legarra, A.; García-Tomás, M.; Rafel, O.; Ramon, J. and Piles, M. (2012). Genetic basis of semen traits and their relationship with growth rate in rabbits. J Anim Sci, 90: 1385-1397. 
FEEDING OF SELENIUM \& TRIBULUS TERRESTRIS EXETRACT OF BUCKS 131

Valchev, G.; Ivanov, A.; Grigorova, S.; Kostinbrod and Zlateva, N. (2009).A study on the effect of Tribulus terrestris L. extract as a growth promoter for rabbits. In AGRIS Since, 45: 96-101.

Zhang, H.W. and Chan, K. (2015). Tribulus terrestris is an herb belonging to the Zygophyllaceae family, which is indigenous to the Southern Europe, Southern Asia, Australia, and Africa. In: Side Effects of Drugs Annual, A Worldwide Yearly Survey Of New Data In Adverse Drug Reactions. Vol. 57:595-601

\section{الاستجابة الفسيولوجية وجودة الهـ نوى الـ سائ ل لذكور الارانب لاضافة السيلينيوم ومستخلص الحسكة خلال موسم الصيف لألور الراب}

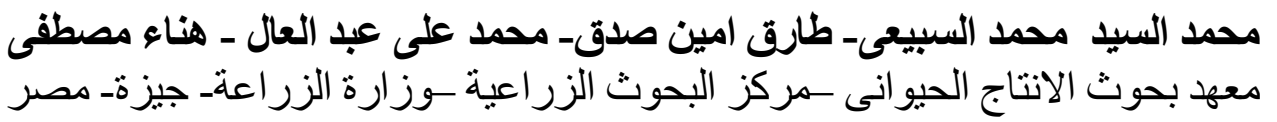

الهاف من هذه الدراسة هو تقييم تأثير اضلفة المستخلص المائي لنبات ترييولوس

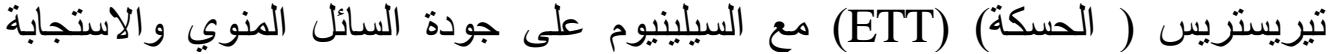

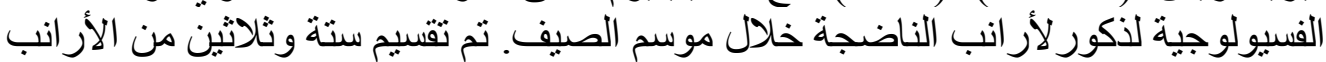

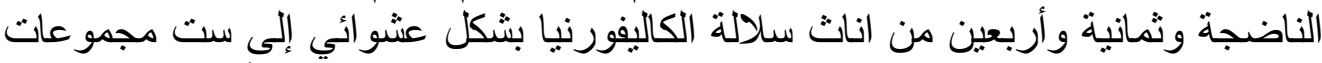

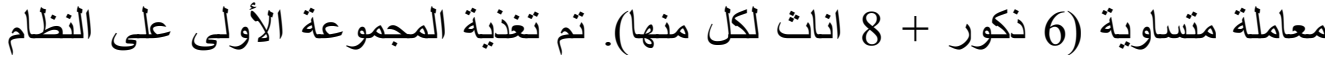

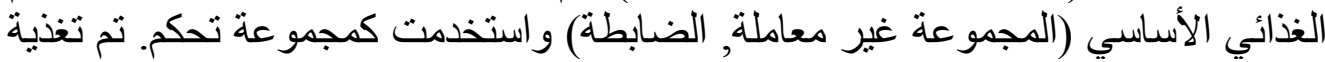

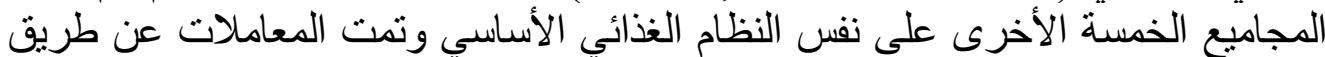

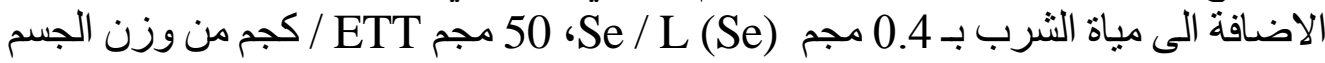

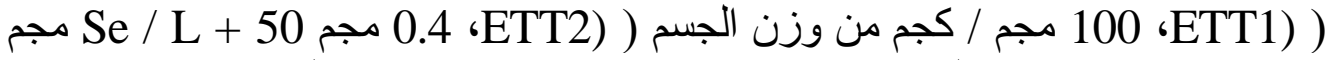
/ كجم من وزن الجسم (ETT

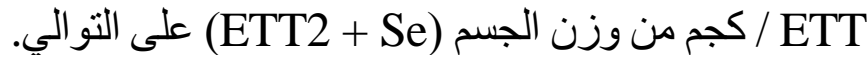

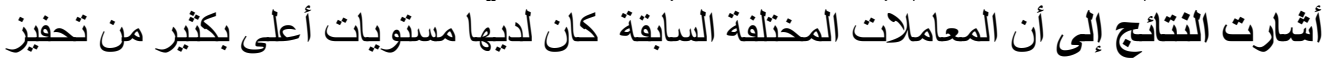

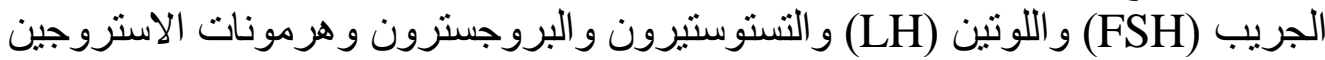

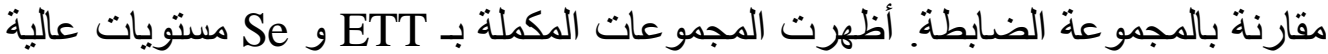

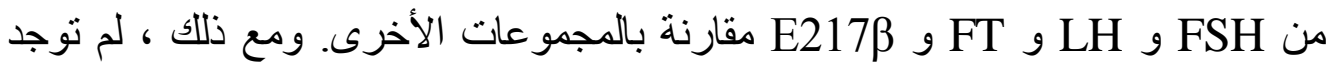


فروق ذات دلالة إحصائية بين جميع المجموعات المكملة فيما بتعلق بمكونات الدم الدام الدئ البيوكيميائية. ادى تناول ETT و Ee إلى زيادة كبيرة في كفائة مضادات الأكسدة الكلية

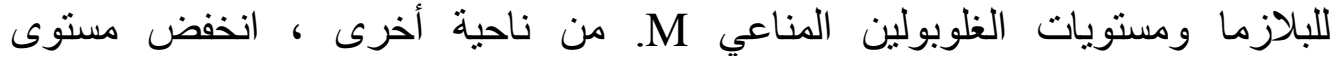
malondialdehyde

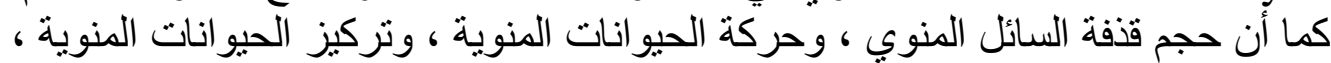

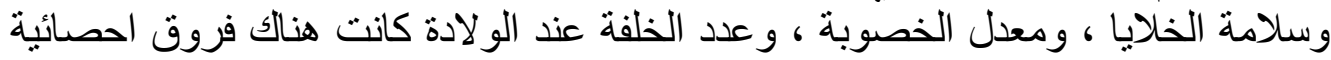

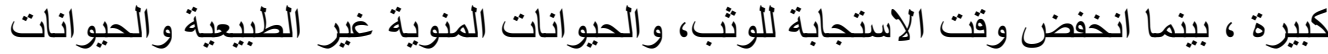

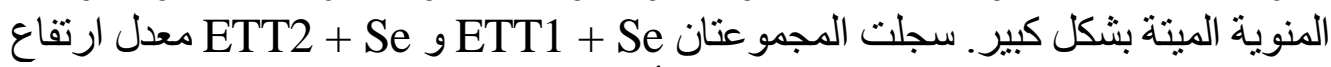

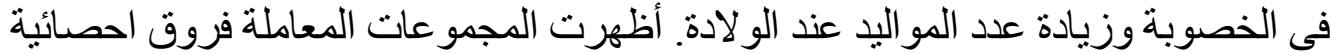

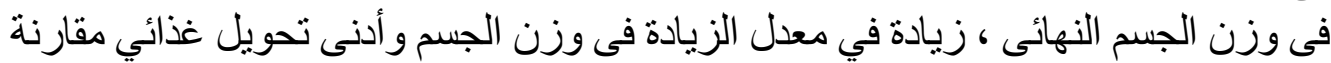
بمجمو عة التحكم. التوصية : أدى مستخلص نبات الحسكة ( تريبولوس تيريستريس) مع السيلينيوم إلى تحسين

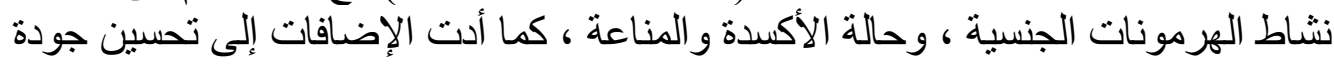

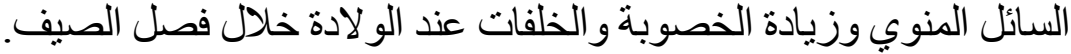

